\title{
Mengembangkan Profesionalisme Guru Pendidikan Agama Islam (PAI) Melalui Model-Model Pembelajaran
}

\author{
Mila Mahmudah \\ STAI Taruna Surabaya \\ Email : milamahmudah91495@gmail.com
}

\begin{abstract}
: learning is a systematic system consisting of various interconnected components. These components are: objectives, materials, methods and evaluation. These four components must be considered in determining learning models that will be used in learning activities. Learning models are arranged based on educational principles, psychological theories, sociology, systems analysis and other theories. Learning models can be selected, meaning that teachers can determine the learning model that will be applied in the learning process in accordance with the situation and conditions of the school environment to achieve learning objectives. Teachers are currently required to develop according to their function, fostering guiding and producing students to achieve educational goals. Curriculum development, administration and equipment facilities must be balanced with the quality of teachers in carrying out the educational process. Because in the whole process of teacher education is a major factor. So it is necessary to improve the quality and professionalism of teachers in carrying out the learning process, especially learning Islamic Religious Education where it can be through mastery of learning models, so that the learning process can develop and not be monotonous.
\end{abstract}

Keywords: professional teachers, learning models, Islamic Religious Education 


\section{Pendahuluan}

Belajar adalah proses interaksi terhadap semua situasi di sekitar.. Belajar dapat dipandang sebagai proses yang diarahkan kepada tujuan dan proses berbuat melalui berbagai pengalaman. ${ }^{1}$ Belajar juga merupakan proses melihat, mengamati dan memahami sesuatu. $^{2}$

Sedangkan kegiatan pembelajaran dapat diartikan sebagai kegiatan dua pelaku, yaitu guru dan siswa. Perilaku guru adalah mengajar sedangkan perilaku siswa adalah belajar. Perilaku keduanya terkait dengan bahan pembelajaran. Bahan pembelajaran dapat berupa ilmu pengetahuan, agama, nilai-nilai kesusilaan, seni, sikap dan ketrampilan. Dan hubungan natara guru, siswa dan bahan ajar bersifat dinamis dsn kompleks.

Dalam pelaksanaan proses pembelajaran dikenal juga model-model pembelajaran sebagai cara untuk menyampaikan materi bahan ajar yang disusun berdasarkan prinsip-prinsip pendidikan, teori-teori psikologis, sosiologis, psikistri, analisis sistem, atau teori-teori lain. Joyce dan weil berpendapat bahwa model pembelajaran adalah suatu rencana atau pola yang dapat digunakan untuk membentuk kurikulum dan pembelajaran jangka panjang, merancang bahan-bahan pembelajaran, membimbing siswa di dalam atau di luar kelas. Model pembelajaran bisa dijadikan pilihan para guru untuk mencapai tujuan pembelajaran.

Para guru menyadari bahwa profesinya adalah suatu yang terhormat dan mulia. Guru mengabdikan dan berbakti untuk mencerdaskan bangsa dan meningkatkan kualitas manusia seutuhnya, yaitu beriman, bertakwa, dan berakhlak mulia, serta menguasai ilmu pengetahuan dalam mewujudkan masyarakat yang berkualitas. Para guru di harapkan mampu tampil secara profesional dengan tugas utamanya adalah mendidik, membimbing, melatih dan mengembangkan kurikulum ( perangkat kurikulum). Seorang guru yang setiap hari melaksanakan tugas mengajar adalah prioritas utama.

\footnotetext{
${ }^{1}$ Rusman 2012 Model-Model Pembelajaran , Jakarta PT Raja Grafindo Persada hal :1

${ }^{2}$ Nana Sudjana 1989 Dasar-dasar Proses Belajar Mengajar, Bandung ; CV Sinar Baru hal; 28
} 


\section{Pengertian Profesioanalisme Guru}

Profesioalisme berasal dari kata profesi artinya suatu bidang pekerjaan yang ingin ditekuni oleh seseorang. Dapat juga diartikan suatu jabatan atau pekerjaan yang mensyaratkan pengetahuan dan ketrampilan khusus yang diperoleh dari pendidikan akademis yang intensif. ${ }^{3}$ Secara etimologi profesi berasal dari bahasa Inggris, yaitu profesission yang artinya mengakui, adanya pengakuan, menyatakan mampu, atau ahli dalam melakukan suatu pekerjaan. Sedangkan secara terminologi, profesi berarti suatu pekerjaan yang mensyaratkan pendidikan tinggi bagi pelakunya yang ditekankan pada pekerjaan mental, yaitu adanya syarat penhetahuan teoritis sebagai instrumen untuk melakukan perbuatan praktis, bukan perbuatan manual (Danin, 2002). ${ }^{4}$

Profesi adalah suatu jabatan atau pekerjaan yang menuntut keahlian tertentu. Artinya, jabatan profesional tidak bisa dilakukan atau dipegang oleh sembarang orang yang tidak terlatih. Melainkan melalui proses pendidikan dan pelatihan yang disiapkan secara khusus untuk bidang tertentu. Misalkan, seorang guru profesional yang memiliki kompetensi keguruan melalui pendidikan guru (PGSD, SI kependidikan, AKTA Pendidikan )yamg diperoleh melalui pendidikan khusus untuk bidang tersebut. Jadi kompetensi guru tersebut diperoleh melalui apa yang disebut profesionalisasi. Profesi dapat diartikan juga sebagai suatu jabatan atau pekerjaan yang mensyaratkan pengetahuan dan ketrampilan khusus yang diperoleh dari pendidikan akademis yang intensif (Webster, 1989).

Berdasarkan pendapat diatas, dapat disimpulkan bahwa profesi adalah suatu bidang pekerjaan atau keahlian tertentu yang mensyaratkan kompetensi intelektualitas, sikap, dam ketrampilan tertentu yang diperoleh melalui proses pendidikan secara akedemis yang intensif.

Profesional adalah pekerjaan atau kegiatan yang dilakukan oleh seseorang dan menjadi sumber penghasilan kehidupan yang memerlukan keahlian atau kecakapan

\footnotetext{
${ }^{3}$ Rusman 2012 Model-Model Pembelajaran PT Jakarta PT Raja Grafindo Persada hal ; 16

4 Danin, 2002. Konsep Profesi Keguruan. Available ; http;//qade.wordpress.com/2009/02/11/profesikeguruan/.
} 
yang memenuhi mutu dan norma tertentu serta memerlukan pendidikan profrsi (UU No 14 Tahun 2005 tentang Guru dan Dosen)

Pengertian profesionalisme adalah suatu pendangan terhadap keahlian tertentu yang mana kaeahlian hanya diperoleh dari pendidikan khusus. ${ }^{5}$ Oemar hamalik bahwa guru profesional merupakan orang yang menempuh program pendidikan guru serta telah menerima ijazah negara dan berpengalaman dalam mengajar. ${ }^{6}$

Profesionalisme Guru merupakan kondisi, arah, nilai, tujuan, dan kualitas suatu keahlian dan kewenangan dalam bidang pendidikan dan pembelajaran yang berkaitan dengan pekerjaan seseorang yang menjadi mata pencaharian. Sementara itu, guru yang profesional adalah guru yang memiliki kompetensi yang dipersyaratkan untuk melakukan tugas pendidikan dan pembelajaran.

\section{Pendidikan Agama Islam}

Pendidikan agama Islam adalah usaha sadar dan terencana dalam menyiapkan siswa untuk mengerti memahami dan mengenal sehingga mampu mengimani ajaran agama Islam. Dalam penyampiannya harus disertai dengan tuntutan untuk menghormati penganut agama lain sehingga tercipta toleransi dan kerukunan antar umat beragama.

Pendidikan Agama Islam di sekolah bertujuan untuk menciptakan dan meningkatkan pengetahuan peserta didik terhadap agama Islam sehingga mampu memahami dan menjalankan ajaran agama Islam dengan baik. Sehingga mampu menjadi muslim yang bertakwa dalam berkembangan kehidupannya.

Pendidikan Agama Islam dalam pelaksanaanya harus mengacu pada ajaran dan nilai-nilai Islam dan tidak melupakan moralitas sosial. Hal ini bertujuan untuk menuai keberhasilan kehidupan peserta didik baik dunia dan mampu membawa kebaikan di akhirat.

\footnotetext{
${ }^{5}$ Arifin 1995 Kapita Selekta Pendidikan (Islam dan Umum), Jakarta : Bumi Aksara, hal 105

${ }^{6}$ Oemar hamalik 1986 Media Pengajaran Bandung : Alumni IKIP hal ; 27 


\section{Pentingnya Profesioanl Guru dalam Pendidikan}

Di dalam dunia pendidikan, guru adalah seorang pendidik, pembimbing, pelatih, dan pengembang kurikulum yang dapat menciptakan kondisi dan suasana belajar yang kondusif, yaitu suasana belajar menyenangkan, menarik, memberi rasa aman, memberikan ruang pada siswa untuk berfikir aktif dan iniovatif dalam mengembangkan kemampuannya.

Guru profesional merupakan faktor penentu proses pendidikan yang berkualitas. Untuk dapat menjadi seperti itu, mereka harus mampu mengaktualisasi diri sesuai dengan kemampuan dan kaidah-kaidah guru yang profesional. Guru dalam era teknologi informasi dan komunikasi saat ini bukan hanya sekedar mengajar melinkan menjadi manager belajar. Setiap guru diharapkan menciptakan situasi belajar yang merangsang kreativitas siswa, menggunakan multimedia, multimetode dan multisumber agar tercapai tujuan pembelajaran.

Pentingnya profesionalisme guru dilandasi oleh beberapa $\mathrm{hal}^{7}$, yaitu :

a. Subjek pendidikan adalah manusia yang memiliki kemauan, pengetahuan dan perasaan

b. Pendidikan dilakukan secara intensional yaitu secara sadar bertujuan, maka yang nomratif dan diikat oleh norma-norma dan nilai-nilai universal, nasional, maupun lokal yang merupakan acuan para pendidik, peserta didik dan pengelola pendidikan.

c. Teori-teori pendidikan merupakan jawaban kerangka hipotesis dalam menjawab permasalahan pendidikan.

d. Pendidikan bertolak dari asumsi pokok tentang manusia, yakni manusia mempunyai potensi yang baik untuk berkembang. Oleh sebab itu, pendidikan itu adalah usaha untuk mengembangkan potensi unggul tersebut.

e. Inti pendidikan terjadi dalam prosesnya, yakni situasi di mana terjadui hubungan antara peserta didik dan pendidik yang memungkinkan peserta didik tumbuh ke arah yang dikehendaki oleh pendidik agar selaras dengan nilai-nilai yang dijunjung tinggi masyarakat.

f. Sering terjadinya dilema antara tujuan utama pendidikan, yaitu menjadikan manusia sebagai manusia yang baik (dimensi instrinsik) dengan misi

\footnotetext{
${ }^{7}$ Sanusi 1991, Studi Pengembangan model Pendidikan Profesional Tenaga Kependidikan, Bandung ; IKIP Bandung, hal ;23
} 
instrumental, yakni yang merupakan alat untuk perubahan untuk mencapai sesuatu.

\section{Pengertian Model-model Pembelajaran}

Joyce and Weil berpendapat bahwa model pembelajaran adalah suatu rencana atau pola yang dapat digunakan untuk membentuk kurikulum ( rencana pembelajaran jangka panjang) merancang bahan-bahan pembelajaran, dan membimbing pembelajaran di kelas atau yang lain. ${ }^{8}$ Model pembelajaran bisa dijadikan pilihan, artinya guru bisa memilih model pembelajaran yang sesuai dan efisein untuk mencapai target dan tujuan pendidikan.

Model-model pembelajaran disusun berdasarkan berbagai teori dan prinsip pengetahuan para ahli menyusun model pembelajaran berdasarkan prinsip pembelajaran, sosiologis, teori psikologis, analisis sistem, atau teori lainnya yang mendukung.

\section{Ciri-ciri Model pembelajaran}

Model pembelajaran memiliki ciri-ciri sebagai berikut :

a. Berdasarkan teori pendidikan dan teori belajar dari para ahli tertentu, contoh model pembelajaran kelompok disusun oleh Herbert Thelen dan berdasarkan teory John dewey. Model ini dirancang untuk melatih partisipasi dalam kelompok secara demokratis.

b. Mempunyai misi atau tujuan pendidikan tertentu, misalnya model berfikir induktif disiapkan untuk mengembangkan proses berfikir induktif.

c. Dapat dijadikan pedoman untuk perbaikan kegiatan belajar mengajar di kelas.

d. Memiliki bagian-bagian model yang dinamakan (1) urutan langkah-lamgkah pembelajaran (2)adanya prinsip-prinsip reaksi (2) sistem sosial (4) sistem pendukung. Keempat bagian tersebut merupakan pedoman praktis bila guru akan melaksankan suatu model pembelajaran.

e. Memiliki dampak sebagai akibat penerapan model pembelajaran

f. Membuat persiapan mengajar dengan pedoman model pembelajaran yang dipilih.

\footnotetext{
8 Joyce, Bruce \& Marsha Weil, 1980. Models of Teaching, fifth edition. UAS ; Allyn and Bacon A Simon \& Scuster Company.hal ; 1
} 
Joyce \& Weil mengelompokan model pembelajaran menjadi empat model pembelajaran. ${ }^{9}$

\section{Model Interaksi Sosial}

Model ini didasari teori belajar Gestalt, menitikberatkan hubungan yang harmonis antara individu dan masyarakat. Pokok pandangan Gelsalt adalah peristiwa tertentu atau objek dipandang sebagai suatu keseluruhan yang terorganisasikan. Makna suatu objek atau peristiwa adalah terletak pada keseluruhan bentuk dan bukan bagian-bagiannya. ${ }^{10}$

Aplikasi teori Gelsalt dalam pembelajaran adalah :

a. Pengalaman dalam proses pembelajaran siswa hendaknya memiliki kemampuan, yaitu kemampuan mengenal keterkaitan unsur-unsur dalam suatu objek. Guru diharapkan mampu mengembangkan kemampuan siswa dalam memecahkan masalah dengan pengalaman.

b. Pembelajaran yang bermakna, mankan unsur-unsur yang terkait adalam suatu objek akan menunjang pembentukan pemahaman dalam proses pembelajaran.

c. Perilaku bertujuan. Perilaku terarah pada suatu tujuan. Pembelajaran terjadi karena siswa memiliki harapan tertentu. Sebab itu pemeblajaran akan berhasil bila siswa mengetahui tujuan yang dicapai.

d. Prinsip ruang hidup, dikembangkan oleh Kurt Lewin. Perilaku siswa terkait dengan lingkungan di mana dia berada. Materi pembelajaran hendaknya memiliki kaitan dengan situasi lingkungan dimana siswa berada (konstektual).

Model interaksi sosial ini meliputi strategi dalam pembelajaran, antara lain

a. Kerja kelompok, bertujuan mengembangkan ketrampilan berperan serta dalam proses bermasyarakat dengan mengembangkan hubungan interpersonal dan discovery skiil dalam bidang akademik.

b. Pertemuan kelas, bertujuan mengembangkan pemahaman mengenai diri sendiri dan rasa tanggung jawab, baik terhadap diri sendiri maupun terhadap kelompok.

\footnotetext{
9 Rusman 2012 Model-Model Pembelajaran PT Jakarta PT Raja Grafindo Persada hal ; 133

${ }^{10}$ Ibid hal;137
} 
c. Pemecahan masalah sosial atau social Inquiry, bertujuan untuk mengembangkan kemampuan memecahkan masalah-masalah sosial dengan cara berfikir logis.

d. Bermain peranan, bertujuan untuk memberikan kesempatan kepada siswa menemukan nilai-nilai sosial dan priadi dalam sitiasi tiruan

e. Simulasi Sosial, bertujuan untuk membantu siswa mengalami berbagai kenyataan sosial serta menguji reaksinya.

\section{Model Pemrosesan Informasi}

Model ini didasarkan teori brlajar kognitif (Piaget) dan berorientasi pada kemampuan siswa memproses informasi yang dapat memperbaiki kemampuannya. Asumsinya adalah pembelajaran adalah faktor yang sangat penting dalam perkembangan. Perkembangan merupakan hasil komulatif pembelajaran.

Dalam pembelajaran terjadi penerimaan imformasi yang diolah sehingga menjadi output dalam bentuk hasil belajar. Dalam pemosesran informasi terjadi interaksi antara kondisi internal ( kondisi siswa, proses kognitif) dan kondisi eksternal (rangsangan dari lingkungan) dan keduanya akan menghasilkan hasil belajar.

Delapan fase proses pembelajaran menurur Robert M, Gagne pelopor model pembelajaran Pemrosesan Informasi :

a. Motivasi, adanya dorongan untuk melakukan suatu tindakan dalamm mencapai tujuan ( motivasi intriksik dan ekstrinsik)

b. Pemahaman, individu menerima informasi yang diperoleh dari proses pembelajaran.

c. Pemerolehan, individu memberikan makna/mempersepsikan segala informasi yang diterima sehingga terjadi proses penyimpanan dalam memori siswa.

d. Penahanan, menahan informasi hasil belajar agar dapat digunakan untuk jangka panjang.

e. Ingatan kembali, mengeluarkan kembali informasi yang telah disimpan, bila asa stimulus.

f. F. Generalisasi, menggunakan hasil pembelajaran untuki keperluan tertentu. 
g. Perlakuan, perwujudan perubahan perilaku individu sebagai hasil pembelajaran.

h. Umpan Balik, individu memperoleh feedback dari perilaku yang dilakukannya.

Sembilan langkah yang harus diperhatikan guru dalam penerapan pembelajaran pemrosesan informasi.

a. Melakukan tindakan untuk memulai aktivitas pembelajaran

b. Memberikan informasi mengenai tujuan dan topik materi yang dibahas.

c. Meransagsang aktivitas siswa dalam proses pembelajaran.

d. Menyampaikan isi pembelajaran sesuai topik materi pembelajaran.

e. Memberi bimbingan pada aktivitas siswa dalam proses pembelajaran.

f. Memberikan penguatan pada perilaku siswa.

g. Memberikan feedback terhadap perilaku siswa.

h. Melaksanakan penilaian proses dan hasil.

i. Memberikan kesempatan kepada siswa untuk tanya jawab berdasarkan pengalamannya.

Model Proses Informasi ini meliputi beberapa stategi pembelajaran, di antaranya :

a. Mengajar Induktif, yaitu untuk mengembangkan kemampuan berfikir dan membentuk teori.

b. Latihan Inquiry, yaitu untuk mencari dan menemukan informasi yang memang diperlukan.

c. Inquiry Keilmuan, bertujuan untuk mengajarkan sistem penelitian dalam disiplin ilmu, dan diharapkan akan memperoleh pengalaman dalam domain-domain disiplin ilmu lainnya.

d. Pembentukan konsep, bertujuab mengembangkan cara berfikir induktif, mengembangkan konsep, dan kemampuan menganalisis.

e. Model Pengembangan, bertujuan untuk mengembangnan kemampuan umum, berfikir logis, sosial dan moral.

3. Model Personal (Personal Models)

Model ini bertitik tolak dari teori humanistik, yeitu berorientasi terhadap pengembangan dari individu. Perhatian utamanya terhadap emosional siswa untuk mengembangkan hubungan yang produktif dengan 
lingkungannya. Model ini diharapkan mampu menjadikan siswa bisa membentuk hubungan yang harmonis serta mampu memproses informasi secara efektif.

Model ini juga berdasarkan pada individu dan perkembangan keakuannya. Tokoh humanistik adalah Abraham Maslow (1962), R. Rogers, c. Buhler, dan Arthur Comb. Menurut teori ini, guru harus bisa berupaya belajar dan mengembangkan dirinya, baik emosional maupun intelektual. Pada teori ini pendidik seharusnya berperan sebagai pendorong, bukan menahan sensitifitas siswa terhadap perasaannya.

Implikasi teori humanistik dalam pendidikan;

a. Bertingkah laku dan belajar adalah hasil pengamatan

b. Tingkah laku yang ada dapat dilaksanakan sekarang (learning to do)

c. Semua individu memiliki dorongan dasar terhadap aktualisasi diri.

d. Tingkah laku individu sebagian besar adalah hasil konsep sendiri.

e. Mengajar adalah bukan hal penting, rapi belajar adalah sangat penting (learn how to learn)

f. Mengajar adalah membantu individu untuk mengembangkan suatu hubungan yang produktif dengan lingkungannya dan memandang dirinya sebagai individu yang cakap.

Model pembelajaran personal meliputi beberapa strategi pembelajaran sebagai berikut

a. Pembelajaran non-direktif, bertujuan membentuk kemampuan dan perkembangan pribadi

b. Latihan kesadaran, bertujuan untuk meningkatkan kemampuan interpersonal siswa.

c. Sintetik, untuk mengembangkan kreativitas dan memecahkan masalah secara kreatif.

d. Sistem konseptual, untuk meningkatkan kompleksitas dasar pribadi yang luwes.

4. Model Modifikasi Tingkah Laku (Behavioral)

Model ini berdasarkan teori belajar behavioristik, yeitu bertujuan mengembangkan sistem yang efisien untuk mengurutkan tugas-tugas belajar dan membentuk tingkah laku dengan cara memanipulasi penguatan. Model ini 
difokuskan kepada aspek perubahan perilaku psikologis dan perilaku yang tidak diamati. Karateristik dari model pembelajaran ini adalah penjabaran tugas-tugas yang dipelajari siswa lebih efisien dan berurutan. ${ }^{11}$

Empat fase dalam model ini adalah :

a. Fase mesin pembelajaran (CIA dan CBI)

b. Penggunaan media

c. Pengajaran berpropagama (linier dan branching)

d. Operant conditioning dan operant reiforcement

Impelemntasi model modifikasi tingkah laku ini adalah : meningkatkan ketelitian pengucapan pada anak, guru, selalu perhatian terhadap tingkah laku belajar siswa, modifikasi tingkah laku anak yang berkemampuan belajar rendah dengan memberikan reward, sebagai reinforcement pendukung, dan penerapan prinsip pemebelajaran individual (individual learning) terhadap pembelajaran klasikal.

\section{Kesimpulan}

Pembelajaran merupakan proses interaksi antara guru dan siswa, baik secara langsung dalam proses tatap muka atau secara tidak langsung., yaitu dengan menggunakan media belajar. Dalam proses pembelajaran tersebut dibutuhkan profesionalisme Guru agar semua proses dapat mencapai tujuan dan target pembelajaran. Profesionalisme Guru merupakan kondisi, arah, nilai, tujuan, dan kualitas suatu keahlian dan kewenangan dalam bidang pendidikan dan pembelajaran yang berkaitan dengan pekerjaan seseorang yang menjadi mata pencaharian.

Pelaksanaan Program pembelajaran dalam satu jam pertemuan diperlukan pengetahuan dan ketrampilan teknis. Juga aspek-aspek kepribadian berpengaruh dalam pelaksanaan suatu kompetensi. Oleh karena itu perbuatan prpfesional keguruan dikatakan bersifat transaksional dalam arti tergantung pada fihak-fihak dan kondisikondisi dalam suatu kegiatan pembelajaran.

Sementara itu, guru yang profesional adalah guru yang memiliki kompetensi yang dipersyaratkan untuk melakukan tugas pendidikan dan pembelajaran. Dalam

\footnotetext{
${ }^{11}$ Ibid hal ;144
} 
menciptakan profesionalisme Guru dibutuhkan berbagai cara. Salah satu caranya adalah menguasaan terhadap model-model pembelajaran yang bisa diterapkan dalam proses belajar mengajar. Khususnya pada pembelajaran Pendidikan agama Islam, sangat dibutuhkan kemampuan dalam penyampaiannya sehingga pembelajarannya sesuai dengan tujuannya untuk meningkatkan pengetahuan dan pemahaman tentang agama Islam. Tujuan utama dari Pendidikan Agama Islam adalah menciptakan keberhasilan kehidupan peserta didik baik dunia dan mampu membawa kebaikan di akhirat.

Model pembelajaran adalah suatu rencana atau pola yang dapat digunakan untuk membentuk kurikulum ( rencana pembelajaran jangka panjang), merancang bahan-bahan pembelajaran, dan membimbing pembelajaran di kelas atau yang lain.

Model pemebelajaran memiliki ciri-ciri sebagai berikut ;

1. Berdasarkan teori pendidikan dan teori belajar dari para ahli tertentu.

2. Mempunyai misi dan tujuan pendidikan tertentu.

3. Dapat dijadikan pedoman untuk perbaikan kegiatan pembelajaran.

4. Memiliki bagian-bagian model yang dinamakan ;

(a) urutan langkah-langkah pembelajaran

(b) adanya prinsip-prinsip reaksi :

(c) sistem sosial

(d) sistem pendukung.

5. Memiliki dampak sebaai akibat terapan model pembelajaran.

6. Membuat persiapan mengajar berdasarkan model pembelajaran yang dipilih. 
Jurnal Keislaman, Vol. 4, No. 1, Maret

\section{Daftar Pustaka}

Arifin 1995 Kapita Selekta Pendidikan (Islam dan Umum), Jakarta : Bumi Aksara, Hamalik, Oemar 1986 Media Pengajaran Bandung : Alumni IKIP

Danin, 2002. Konsep Profesi Keguruan. Available ;http;//qade.wordpress.com/2009/02/11/profesi-keguruan/.

Rusman 2012, Model-Model Pembelajaran Jakarta : PT. Grafindo Persada

Joyce, Bruce \& Marsha Weil, 1980. Models of Teaching, fifth edition. UAS Allyn and Bacon A Simon \& Scuster Company.

Sanusi, Ahmad, 1991. Studi Pengembangan Model Pendidikan Profesional Tenaga Kependidikan. Bandung ; IKIP Bandung

Sudjana, Nana, 1989. Dasar-dasar Proses Belajar Mengajar. Bandung : CV. Sinar Baru 